\title{
Phylogenetic and morphological evaluation of Wollea saccata (Nostocales, Cyanobacteria) isolated from the Yenissei River basin (Eastern Siberia, Russia)
}

\author{
Igor V. KozhevniKov* \& Nelya A. KozHEVNiKova
}

Siberian Federal University, Svobodny Av. 79, Krasnoyarsk, 660041, Russian Federation; * corresponding author e-mail:ikozhevnikov@inbox.ru

\begin{abstract}
For the first time the genus Wollea Bornet et Flahault was recorded in Eastern Siberia (Yenissei River, Karskoe See Basin) and isolated to monoclonal axenic strain ACCS 045. The strain was characterized by a combination of morphological and molecular approaches. It shares the diacritical features of the type-species $W$. saccata (Wolle) Bornet et Flahault and W. bharadwajae R.N. Singh such as macroscopic gelatinous colonies, tube-like, trichomes more or less straight or slightly curved, sheaths around trichomes are absent, heterocytes intercalary, and paraheterocytic akinete development at both sides of heteocytes in short series. A morphological comparison shows that it differs from $W$. saccata in the form of colonies being saccule, the form of vegetative cells and the heterocytes being barrel-shaped, the form of terminal cells being conical-rounded, and from $W$. bharadwajae in the form of akinetes being cylindrical or ellipsoid. The first available 16S rRNA gene sequence of Wollea appeared poorly related to other cyanobacterial sequences. According to the traditional classification systems based on morphological and ecological observations genus Wollea appears closest to Anabaena and Nostoc. However, the phylogenetic placement of Wollea based on 16S rRNA gene sequence was distant from Nostoc and the most closely related to taxa in benthic Anabaena, Sphaerospermopsis, Cylindrospermopsis, and Raphidiopsis.
\end{abstract}

Key words: Wollea saccata, cyanobacteria, 16S rRNA gene, taxonomy, morphology

\section{Introduction}

The genus Wollea includes filamentous and heterocytous colonial cyanobacteria. Originally, the type species was described from stagnant ponds of North America (New Jersey) as Sphaerozyga saccata by Wolle (1880, 1887), and later, the new monotypical genus Wollea was established by Bornet and Flahault (1888). Later, tree additional species were described from littoral of freshwater ponds and paddy field bottom in India ( $W$. bharadwayae R.N. SINGH (1942) and W. udaipurensis GUPTA et KUMAR (1968)) and as endophytic into parenchyma of aquatic plant Lemna trisulca from freshwater pond in Spain ( $W$. lemnae Guerrero (1947)). Furthermore, according to the important generic characters, the following taxons Anabaena ambigua RAO, Anabaena vaginicola FrITSCH et Rich, Anabaenothrix cylidrica Randhawa, and Anabaenothrix epiphytica Randhawa are included in the genus Wollea (SINGH 1942).
Currently, the genus Wollea belongs to order Nostocales, family Nostocaceae by traditional classification (KOMÁREK \& ANAGNOSTIDIs 1989) and subsection IV.I by bacteriological classification (CAstenholtz 2001). Wollea $\mathrm{spp}$. are characterized by macroscopic gelatinous colonies which are smooth on the surface, more or less cylindrical or subspherical (sometimes tube-like). Trichomes are more or less straight or slightly curved, uniseriate, not branched, not attenuated or widened at the ends, intensely constricted at cross walls; irregularly or more or less parallel and densely arranged in common, and diffluent mucilage. Terminal cells are rounded. Sheaths around trichomes are absent. Heterocytes are intercalar, solitary. Akinetes arise paraheterocytic in short series at both sides of heteocystes, spherical or oval (KOMÁREK \& HAUER 2010). Wollea is most morphologically similar to genera Anabaena and Nostoc.

To date, the phylogenetic relationship between Wollea and other genera of family Nostocales 
have not been determined. In this connection, we investigated morphological characters and molecular organization of $16 \mathrm{~S}$ rRNA gene of the strain of $W$. saccata.

\section{Material and Methods}

The strain W. saccata ACCS 045 was isolated from pelagic phytoplankton samples of the Yenissei River (Karskoe See basin) near Igarka city located in Northern of Eastern Siberia. Isolation was carried out by repeated transfers of single trichomes on solid $\mathrm{BG}_{11}$ liquid medium without nitrogen (RIPPKA et al. 1979) under continuous light intensity of 30-40 $\mu$ mol.m ${ }^{2} . \mathrm{s}^{-1}$ photons at $22-25^{\circ} \mathrm{C}$. This strain is maintained in culture collection of the Siberian Federal University in Krasnoyarsk, Russia, under the number ACCS 045. Detailed morphological analyses were carried out on cultures during the period of 1-3 months after the isolation from nature using Meiji ML2000 light microscope (Meiji Techno, Japan). Microphotographs were taken with Infiniti I camera (Luminera, Canada).

Extraction of DNA was carried out using a commercial AquaPure Genomic DNA Isolation reagent kit (BioRad, USA), following the manufacturer's protocol. The 16S rRNA gene was amplified using the universal primers 27F (5'-AGAGTTTGATCCTGGCTCAG-3') and 1492R (5'-GGTTACCTTGTTACGACTT-3'), corresponding to Escherichia coli positions 8-27 and $1510-1492$, respectively. Polymerase chain reaction (PCR) was performed using a Mastercycler Gradient amplifier (Eppendorf, Germany) in the total volume 50 $\mu$, containing $50-100 \mathrm{ng}$ of DNA matrix, $1 \mathrm{x}$ reaction buffer, $0.3 \mu \mathrm{M}$ of each primer, $0.2 \mu \mathrm{M}$ of each dNTP, $2 \mu \mathrm{M}$ of $\mathrm{MgSO}_{4}$, and 1 unit of high-fidelity Platinum Taq polymerase (Invitrogen, USA). The PCR was run as follows: primary denaturation at $95^{\circ} \mathrm{C}$ for $3 \mathrm{~min} ; 25$ cycles: at $94{ }^{\circ} \mathrm{C}$ for $30 \mathrm{~s}$, at $55^{\circ} \mathrm{C}$ for $40 \mathrm{~s}$, at $68^{\circ} \mathrm{C}$ for 1 min $30 \mathrm{~s}$; final extension at $68^{\circ} \mathrm{C}$ for $10 \mathrm{~min}$. The sizes, quantity and purity of PCR products were analyzed in a $1.2 \%$ agarose gel, using $0.5 \%$ TAE buffer.

To generate high-quality sequences, unpolished PCR products were cloned in the vector pCR4-TOPO (Invitrogen, USA), used to transform cells of $E$. coli TOP10. The obtained clones were subjected to restriction analysis to determine whether there was an insert of the proper size in the vector. Isolation of plasmid DNA was performed using a PureLink Quick Plasmid Miniprep kit (Invitrogen, USA), following the manufacturer's protocol. Sequencing was done in two directions, on an ALFexpress II DNA analysis system (Amersham Pharmacia Biotech Ltd, USA), using the universal primers T3 and T7 and a Thermo Sequenase Cy5 Dye Terminator kit. The obtained nucleotide sequence of the 16S rRNA gene were deposited in the database of GenBank NCBI under the accession number GU434226.

A total of 87 sequences from heterocytous taxa including Wollea saccata were used. Additional sequences from the databases of GenBank, EMBL, and DDBJ belonging to the genera Anabaena, Anabaenopsis, Aphanizomenon, Cyanospira, Cylindrospermopsis, Cylindrospermum, Dolichospermum, Nodularia, Nostoc, Raphidiopsis, Sphaerospermopsis, and Trichormus were aligned using the ClustalW (1.81) program. Escherichia coli ATCC 8739 was used to root all trees. Phylogenetic trees based on the 16S rRNA gene were constructed by neighbour-joining (NJ), maximum-parsimony (MP) and maximum-likelihood (ML) algorithms using PAUP* v4.02b (SWOFFORD 1998). NJ, MP, and ML analysis were bootstrapped with 1000,1000 and 100 replicates, respectively. The phylogenetic trees had identical topologies. The NJ tree with the indication of bootstrap values obtained with the NJ, MP, and ML approaches is presented in this work.

\section{Results and Discussion}

This is the first report on the occurrence of genera Wollea in Siberia. W. saccata is a freshwater species, which is infrequently reported from the temperate zones of Europe, such as Romania (CĂRĂUŞ 2002), Czech Republic and Slovakia (HINDÁK 2001), the Ukraine (SVIRENKo in ELENKIN 1938), Spain (GuERRERo 1947), and from several localities (mainly standing waters) in North America (KOMÁREK et al. 2003).

Under culture conditions $W$. saccata strain shares the diacritical features of the type-species $W$. saccata and $W$. bharadwajae such as macroscopic gelatinous colonies, tube-like, trichomes more or less straight or slightly curved, sheaths around trichomes are absent, heterocytes intercalary and paraheterocytic akinete development at both sides of heterocytes in short series (Fig. 1-3). A morphological comparison shows that our strain differs from $W$. saccata in the form of colonies being saccule, the form of vegetative cells and heterocytes being barrel-shaped, the form of terminal cells being conical-rounded, and from W. bharadwajae in the form of akinetes being cylindrical or ellipsoid (Table 1).

According to the traditional classification systems based on morphological and ecological observations, genus Wollea appears closest to 


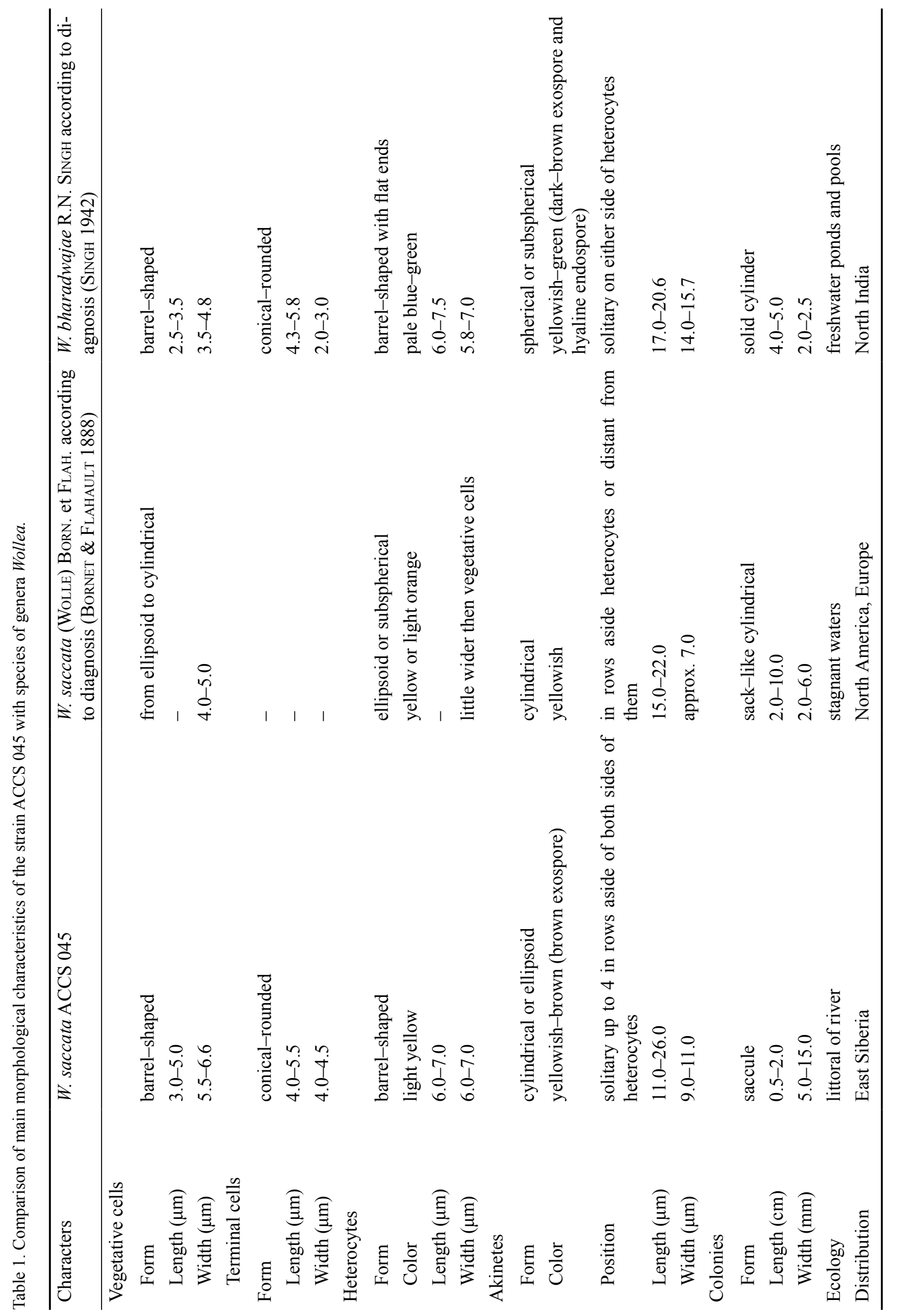



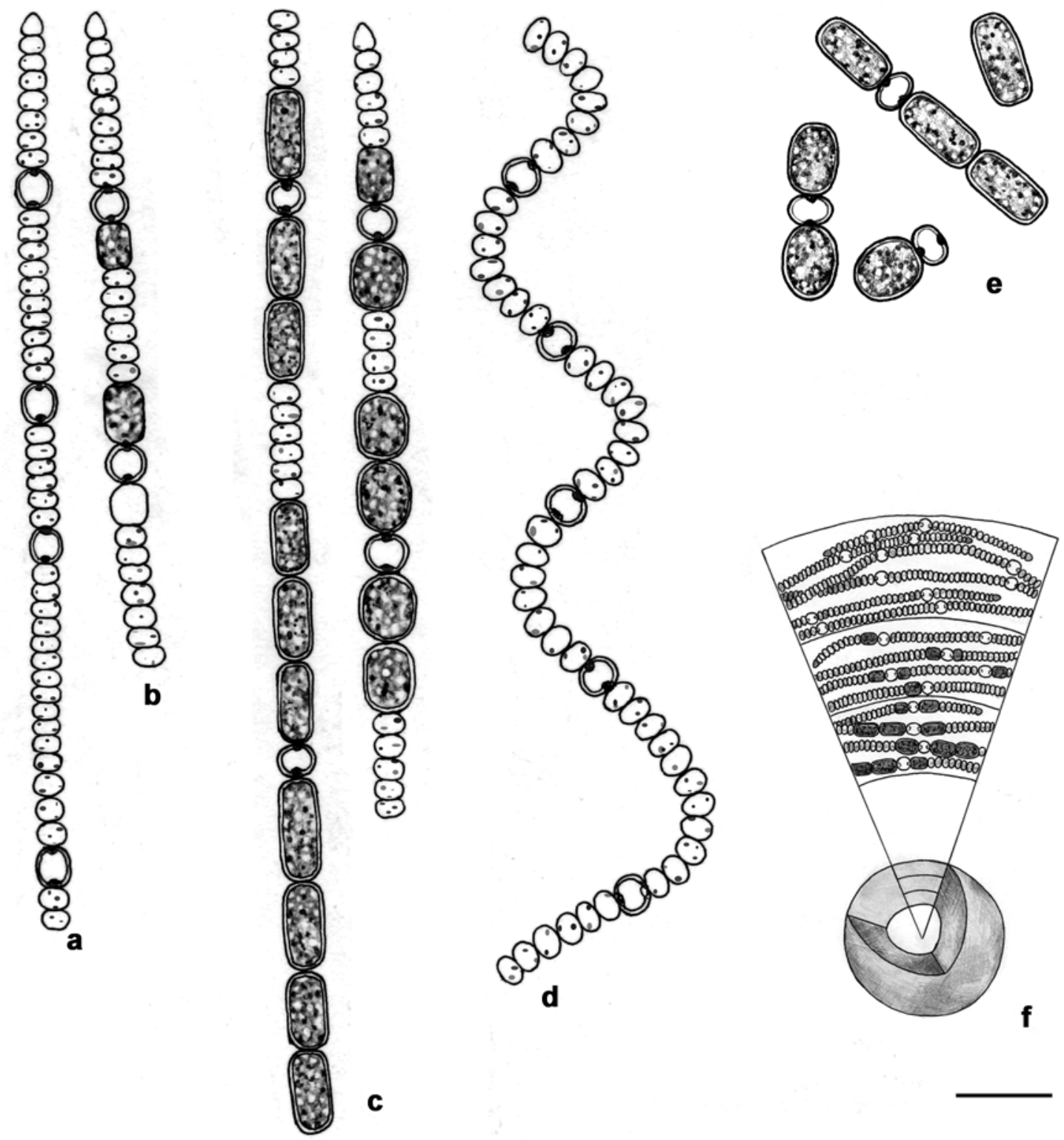

Fig. 1. Iconographs of Wollea saccata strain ACCS 045: (a) trichome showing intercalar heterocytes formation; (b) formation of proakinetes; (c) straight trichomes with akinetes at both sides of heterocytes; (d) curved filament of trichome; (e) ellipsoid and cylindrical ripe akinetes with heterocytes; (f) arrangement of trichomes in saccule spherical colony. Scale bar $10 \mu \mathrm{m}(\mathrm{a}-\mathrm{e})$, $30 \mu \mathrm{m}$ (f.)

Nostoc, Anabaena and Anabaenopsis (KOMÁReK \& Anagnostidis 1989). Bornet \& Flahault (1888, p. 223) record that trichomes and spores of this genus correspond to genus Sphaerozyga (later one of Anabaena sections) to which Wolle $(1880,1887)$ initially referred species $S$. saccata that was described by him. But the original form of the colonies made them establish this alga as a separate genus Wollea placed between Nostoc and Anabaena. Elenkin (1938, p. 641) supposes that genus Wollea was situated much closer to the typical representatives of genus Nostoc than to Anabaena. On the basis of the investigation of $W$. bharadwajae, SiNGH (1942, p. 604) was of opinion that genus Wollea represents a synthetic genus from which two evolutionary lines, one leading to a Nostocoid habit and another to an Anabaenoid habit, have been evolved.

The W. saccata strain ACCS 045 shared less than 95.4\% 16S rRNA gene sequence similarity with any other cyanobacterial sequence and formed common subcluster with the strain 133 of $A n$. cf. cylindrical (similarity 95.4\%), closely together with An. oscillarioides strains BO HINDÁK 1984/43 (similarity 95.1\%) (Fig. 4). Interestingly, 

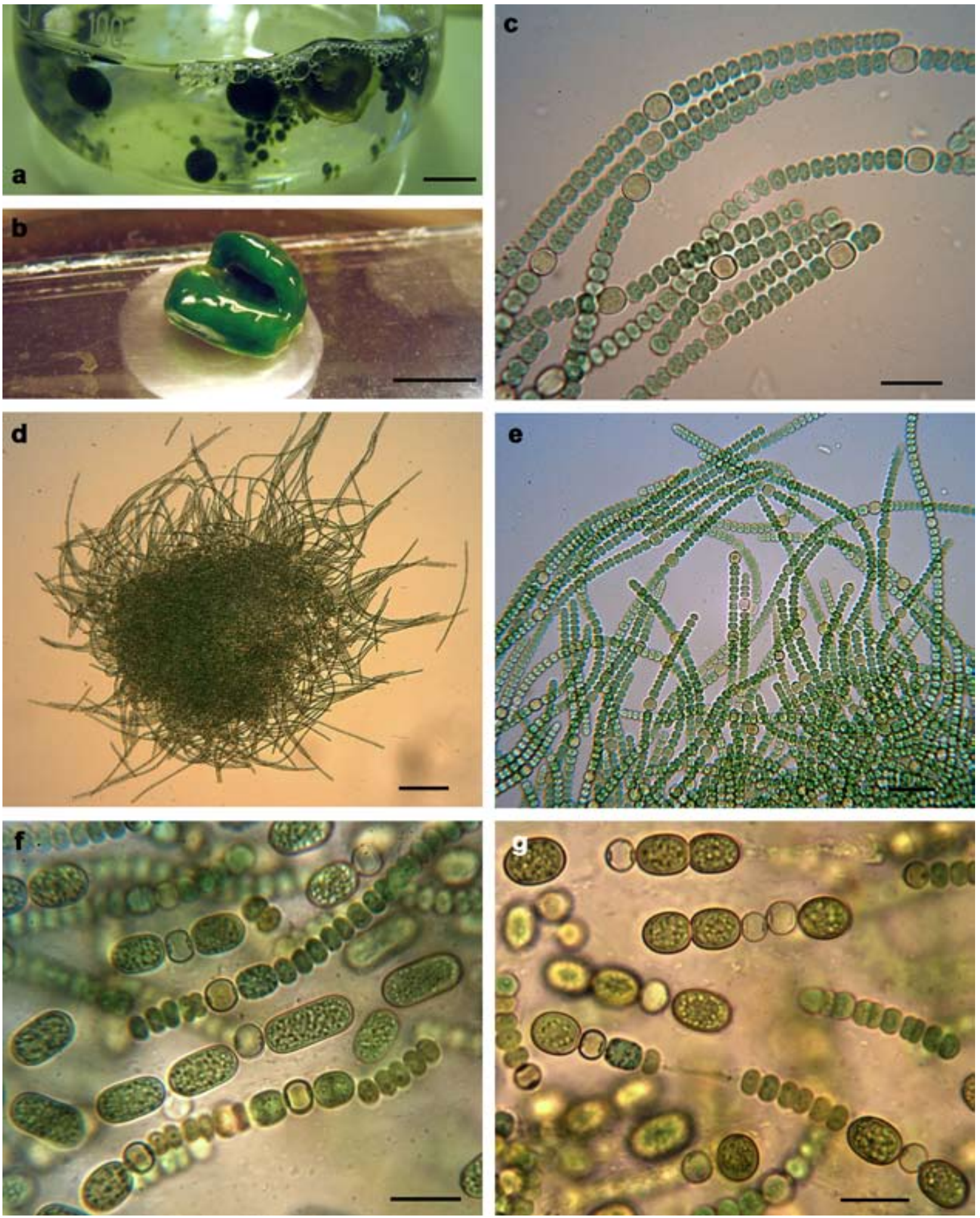

Fig. 2. Microphotographs of Wollea saccata strain ACC 045: (a, b) saccule spherical form of colony; (c) young trichomes with intercalary heterocytes and conical-rounded terminal cells; (d) young colony without apparent mucilage; (e) arrangement of trichomes in the young colonies; (f, g) akinetes formation (cylindrical and ellipsoid). Scale bar $1 \mathrm{sm}(\mathrm{a}-\mathrm{b}), 50 \mu \mathrm{m}(\mathrm{d}), 20 \mu \mathrm{m}$ (e), $10 \mu \mathrm{m}(\mathrm{c}, \mathrm{f}, \mathrm{g})$. 

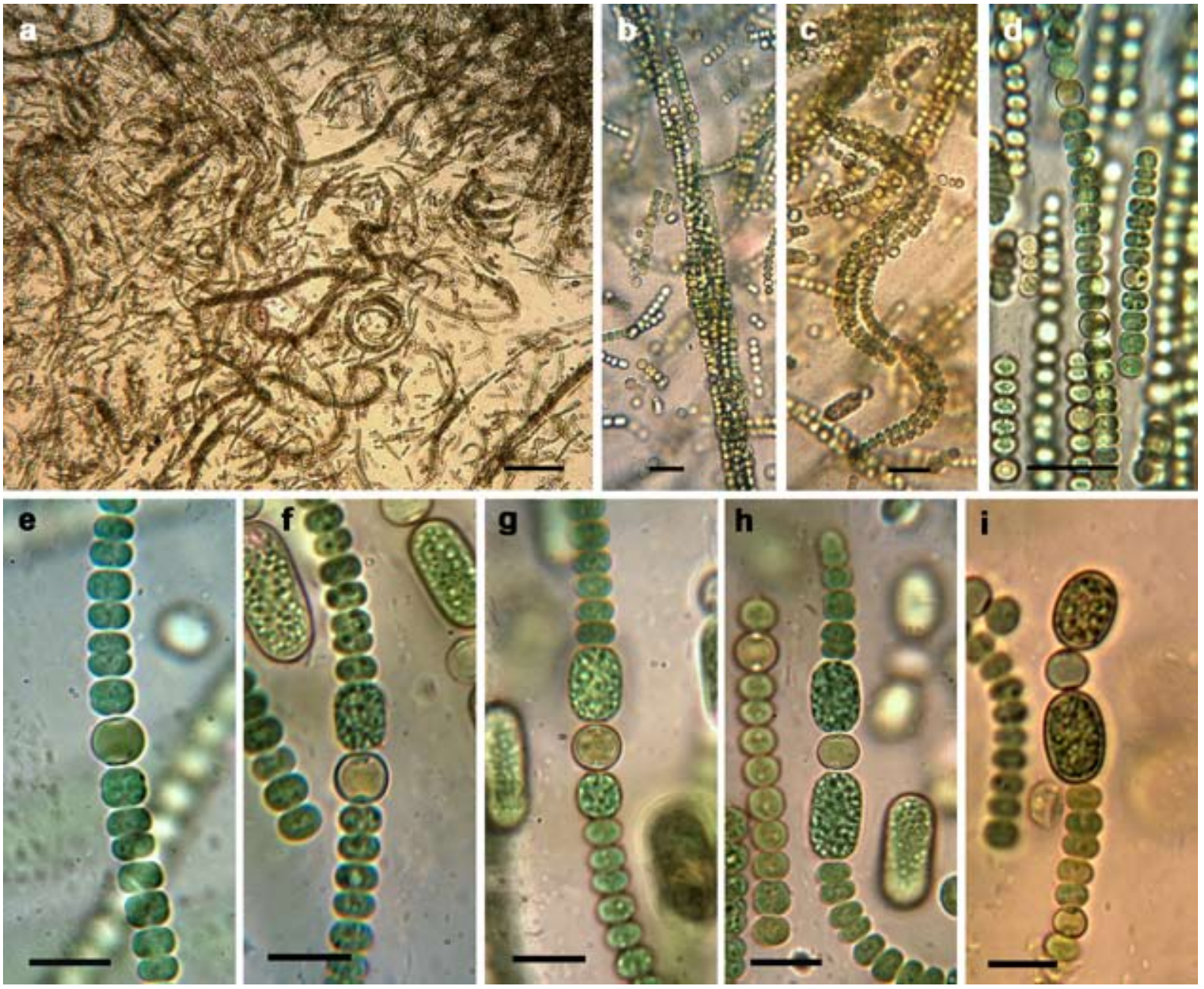

Fig. 3. Wollea saccata strain ACC 045, arrangement of the trichomes in the mature colony and paraheterocytic development of akinetes: (a) filaments of trichomes in the mucilaginous colony; (b) twisted strand of trichomes; (c) curved filament of trichomes; (d) parallel arrangement of the single trichomes; (e) segment of trichome with intercalary heterocyte; (f) trichome with proakinete at one side of heterocyte; $(\mathrm{g}, \mathrm{h})$ trichome with proakinetes at both sides of heterocyte; (i) trichome with ripe ellipsoid akinetes. Scale bar $60 \mu \mathrm{m}$ (a), $30 \mu \mathrm{m}$ (b, c), $20 \mu \mathrm{m}$ (d) and $10 \mu \mathrm{m}(\mathrm{e}-\mathrm{i})$.

Fig. 4. Neighbour-joining tree based on 16S rRNA gene sequences (1193 bp) showing phylogenetic position of studied strain ACCS 045 of Wollea saccata (in bold). Values above nodes indicate bootstrap support over $65 \%$ for the NJ/MP analyses, while values below nodes indicate bootstrap support over $65 \%$ for the ML analysis. OTUs - operational taxonomic units.

W. saccata, An. cylindrical and An. oscillarioides are characterized by similar formation of akinetes at both sides of a heterocyte (paraheterocytic) and conical (conical-rounded) form of terminal cells. Moreover, disregarding the peculiar macroscopic colonial structure of Wollea, and considering only trichomes and cells (including heterocytes and akinetes) morphology, strain ACCS 045 is very similar to An. oscillarioides and An. turkestanica (Kisselev) KomÁrex (former An. oscillarioides $\mathrm{f}$. turkestanica (KISSELEV) ELENKIN).

The strain of Wollea was placed close to Raphidiopsis FrITSCH et RICH (16S rRNA sequence similarity with $W$. saccata less than 92.8\%), Cylindrospermopsis raciborskii (WoŁosz.) Seenaya et Subba Raju (similarity less than 92.8\%), Sphaerospermopsis ZAPOMĚLovÁ, Jezberová, HrouzeK, Hisem, Řeháková et KomÁRKOvÁ (similarity less than 93.6\%) and benthic Anabaena (including An. augstumalis SCHMidKe JAHNKe/4a (similarity $95.2 \%$ )) clusters. The benthic Anabaena-types (former subg. Anabaena) forming mats and never producing gas vesicles in cells were found clearly genetically separated from the planktic cluster (former subg. Dolichospermum) containing free-floating solitary trichomes or their small groups (GUGGER 


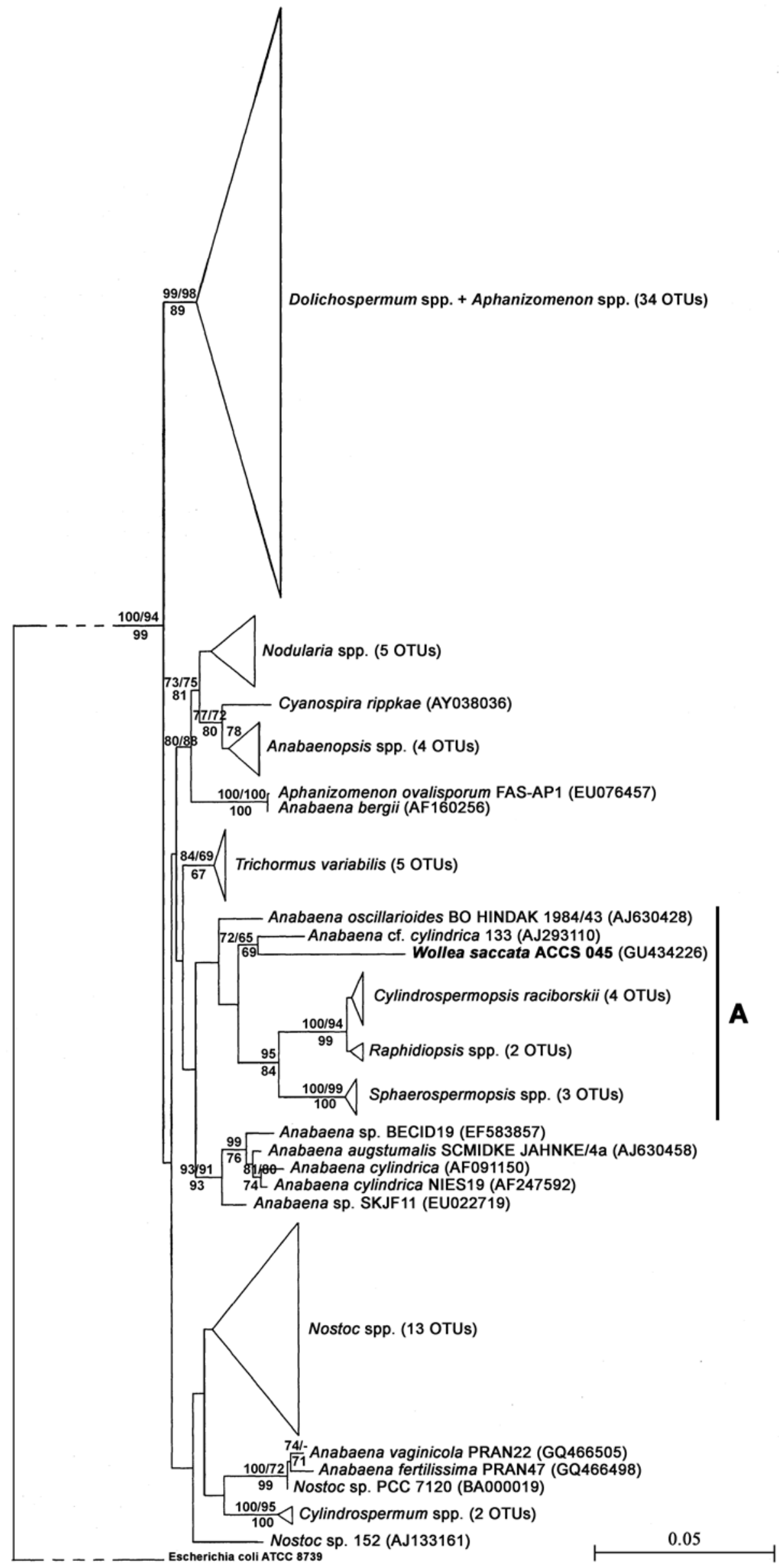


et al. 2002; Rajaniemi et al. 2005). Recently, on the basis of polyphasic data the new genera Sphaerospermopsis (ZAPOMĚLOVÁ et al. 2010) and Dolichospermum (WACKLIN et al. 2009) have been separated from Anabaena.

All members of cluster A (Fig. 4) are characterized paraheterocytic type formation of akinetes except genera Raphidiopsis. Certainly, heterocysts clearly influence the position of akinetes in the filament, yet it has been impossible to provide a unifying model to explain the different types of the akinete development in, e.g., Nostoc and Wollea, in which akinetes form midway between and adjacent to heterocysts, respectively. We suppose that as with the varied triggers for akinete development, it may be that akinete positioning is controlled by different mechanism in different cyanobacteria. But not numerous data available till now including molecular genetics of akinetes and their formation does not allow to estimate evolutionary relevance of different akinete development types.

Thus, our results show that the phylogenetic placement of genera Wollea based on 16S rRNA gene sequence was distant from Nostoc and the most closely related to taxa in benthic Anabaena, Sphaerospermopsis, Cylindrospermopsis, and Raphidiopsis.

\section{Acknowledgements}

The study was supported by grant No. 09-04-01667-a from the Russian Foundation of Basic Research.

\section{References}

Bornet, E. \& Flahault, C. (1888): Revision des Nostocacées hétérocystées. - Ann. Sci. Nat. Bot. 7: 223-224.

CĂRĂUŞ, I. (2002): The algae of Romania. - Studii si Cercetări, Universitatea Bacău, Biologie 7: 1-694.

Castenholz, R.W. (2001): Oxygenic photosynthetic bacteria. - In: Bergey's Manual of Systematic Bacteriology. 2nd ed. - pp. 473-599, New York, Springer.

Elenkin, A.A. (1938): Monographia algarum cyanophycearum aquidulcium et terrestrium in finibus URSS inventarum. Pars specialis (systematica). - pp. 640-642, Sumptibus AS URSS, Moskva-Leningrad.

Guerrero, P.G. (1948): Nuevos datos ficológicos de España. - In: Anales del Jardín Botánico de
Madrid: 265-283.

Gugger, M., Lyra, C., Henriksen, P., Coute, A., Humbert, J.F. \& Sivonen, K. (2002): Phylogenetic comparison of the cyanobacterial genera Anabaena and Aphanizomenon - Int. J. Syst. Evol. Microbiol. 52: 1867-1880.

Hindék, F. (2001): Photographic Atlas of the Microscopic Freshwater Cyanobacteria. - 127 p., Veda, Bratislava.

KomÁreK, J. \& Anagnostidis, K. (1989): Modern approach to the classification system of Cyanophytes 4: Nostocales. - Algological Studies 56: 247-345.

KomÁrek, J. \& Hauer, T. (2010): CyanoDB.cz - Online database of cyanobacterial genera - Wordwide electronic publication, Univ. of South Bohemia \& Inst. of Botany AS CR, http://www. cyanodb.cz

Komárek, J., KomÁrková, J. \& Kling, H. (2003): Filamentous Cyanobacteria - In: SeAth, R.G., WeHr, J.D. \& ThORP, J.H. (eds): Freshwater algae of North America: Ecology and classification. pp. 117-196, Academic Press, San Diego.

Rajaniemi, P., Hrouzek, P., Kaštovská, K., Willame, R., Rantala, A., Hoffmann, L., KomáreK, J. \& Sivonen, K. (2005): Phylogenetic and morphological evoluation of the genera Anabaena, Aphanizomenon, Trichormus and Nostoc (Nostocales, Cyanobateria) - Int. J. Syst. Evol. Microbiol. 55: 11-26.

Rippka, R., Deruelles, J., Waterbury, J.B., Herdman, M. \& STANIER, R. Y.(1979): Generic assignments, strain histories and properties of pure cultures of cyanobacteria. - J. Gen. Microbiol. 111: 1-61.

SingH, R.N. (1942): Wollea Bharadwajae sp. nov. and its Autecology. - Ann. Bot. 6: 593-606.

Wacklin, P., Hoffman, L. \& Komárek, J. (2009): Nomenclatural validation of the genetically revised cyanobacterial genus Dolichospermum (Ralfs ex Bornet et Flahault) comb. nov. Fottea 9: 59-64.

Wolle, F. (1887): Fresh-water Algae of the United States, vol. 2 (plates). - p. 290, The Comenius Press, Bethlehem.

Zapomělová, E., Jezberová, J., Hrouzek, P., Hisem, D., Řeháková, K. \& Komárková J. (2010): Polyphasic characterisation of three strains of Anabaena reniformis and Aphanizomenon aphanizomenoides (Cyanobacteria) and their reclassification to Sphaerospermum gen. nov. (incl. Anabaena kisseleviana) (45: 1363-1373). Nomenclatural note. - J. Phycol. 46: 415.

(C) Czech Phycological Society (2011)

Recieved Sept 2010

Accepted Dec 2010 